University of Nebraska - Lincoln

DigitalCommons@University of Nebraska - Lincoln

Agronomy \& Horticulture -- Faculty Publications

Agronomy and Horticulture Department

10-1935

\title{
Response of the Prairie to the Great Drought of 1934
}

J. E. Weaver

University of Nebraska-Lincoln

L. A. Stoddart

University of Nebraska-Lincoln

W. M. Noll

University of Nebraska-Lincoln

Follow this and additional works at: https://digitalcommons.unl.edu/agronomyfacpub

Part of the Plant Sciences Commons

Weaver, J. E.; Stoddart, L. A.; and Noll, W. M., "Response of the Prairie to the Great Drought of 1934" (1935). Agronomy \& Horticulture -- Faculty Publications. 459.

https://digitalcommons.unl.edu/agronomyfacpub/459

This Article is brought to you for free and open access by the Agronomy and Horticulture Department at DigitalCommons@University of Nebraska - Lincoln. It has been accepted for inclusion in Agronomy \& Horticulture -Faculty Publications by an authorized administrator of DigitalCommons@University of Nebraska - Lincoln. 


\section{RESPONSE OF THE PRAIRIE TO THE GREAT DROUGHT OF $1934 * 1$}

J. E. Weaver, L. A. Stoddart, and Wm. Noll

\section{Unizersity of Nebraska}

Drought during the growing season of 1934 was the greatest ever recorded in the prairie region. It offered an exceptional opportunity to study the response of native plants to extremely adverse water relations. Measurements of the environmental factors of the prairie, in connection with various grassland researches, have now been completed, except for one year, for the seventeenth consecutive growing season. In a summary of findings at the end of twelve years it was stated that although periods of drought are liable to occur at any time, and especially after midsummer, yet only twice during these twelve years was the water content in the surface six inches of soil reduced to the hygroscopic coefficient, i.c. approximately the point where water is nonavailable for growth (Weaver and Himmel, '31). At no time was the available water in the deeper soil entirely exhausted. Drought periods when water was nonavailable in the surface foot occurred during 1931 and 1933 (Flory, '34). Then came the extremely dry summer of 1934 during which the prairie was under the impact of almost continuous drought. These studies were made near Lincoln, Nebraska, but similar conditions prevailed, in general, throughout the tall-grass prairie in the eastern one-third of the state, except in the extreme northeastern part.

\section{The Spring Drought}

After an unusually warm winter with light snowfall, the spring of 1934 began very dry. March had practically no efficient rainfall, a total precipitation of .8 inch occurring in seven different showers. The heaviest shower of April or May was only .24 inch; the total rainfall in April was .35 inch and that of May 49 inch. The arid conditions were accentuated by high winds with an average mean daily velocity of about 12 miles per hour. Frequently these carried great quantities of dust which lodged among the grasses and readily rose again into the air. Temperatures were often abnormally high and much clear weather occurred. The available water content of the upper foot of soil was sufficient, however, for the early blooming grasses and forbs to make a good initial growth.

Poa pratensis developed rapidly, Stipa spartea, Kocleria cristata, and

* Contribution from the Department of Botany, University of Nebraska, no. 92.

1 This article is published out of the order determined by the receipt of the manuscript at the expense of funds other than those of the Ecological Society of America. 
Elymus canadensis all grew well cluring April. Carer pemustanica, Antennaria campestris, Anemone caroliniana. Cogsarellia foeniculacea and other prevernal bloomers developed regetatively in about the usual manner. Their period of anthesis was considerably shortened, however, and the inflorescences somewhat reduced both in number and size (cf. Weaver and Fitzpatrick, 3t). Hence, even this earliest aspect was rather poorly developed in the wind-swept. dust-covered, dried regetation of the previous year.

Many species of the early vernal aspect, which began late in April, developed only poorly, others produced an unusual abunclance of flowers and a large crop of seed. Among the former were l'iola pedatifida, I . papilionacea, Fragaria airginiana, and Allium mutabile. Species of O.ralis grew poorly. Nothocalais cuspidata was far below normal, l'icia americana had but few blossoms, and Sonccio plattensis was dwarfed by the low water content of soil and the dry air. Not inf requently the flowers withered and fried and the production of vialble seed was almost nil. As regards these species, many of which are rather shallowly rooted, the aspect was short and poorly developecl.

Conversely the deeply rooted istragalus crassicarpus dominated the aspect, though later the drought of June withered and dried the half-grown fruits. Baptisia leucophaca blossomed profusely and developed an excellent seed crop). The culms of Equisctum lacrigatum formed unusually dense patches of tall stems and the strobili were very prominent. This species. like the two legumes, extends many feet into the soil (Weaver, '19 and 20). Seed production of Sisyrinchimu angustifolium. S. campestre, and Carex pennsylianica was also large.

Poa pratensis began to bloom with the incoming of the vernal aspect. Its anthesis was hastened by the (lrought. The number of flower stallis was greatly reduced and their height was usually only one-third to one-half normal. In pastures where bluegrass grows in almost pure stands, this species, which is almost entirely rooted in the surface 30 inchess of soil, was practically all (lried by May 15. Since many of the annual pasture weeds, such as Sporobolus neglectus, Schedonnardus paniculatus. Aristida oligantha, and Erayrostis major, failed to germinate, the landscape appeared hare incleed. But in the prairie where the bluegrass was protected by the shade of other grasses and forbs, most of which absorly at greater (lepths as well as in the bluegrass root zone, the half-wilted plants remained green until the last of May. The inability of the invading bluegrass to arljust itself to (loought by greatly increasing its osmotic pressure, as clo most native prairie species, was well illustrated. Osmotic pressure of the cell sap increased very gradually from about 15 atmospheres on April 10 to $29 \mathrm{~A}$ when it completely dried on May $25 .^{2}$

2 Plant materials were frozen in the field with carbon dioxide ice. After 18 hours, sap was extracted from thawed material at a pressure of 10,000 pounds per square inch. The freezing point of the sap was determined at once by use of an appropriate thermometer and an ether-evaporation device and the results are expressed in the osmotic concentration of the cell sap in atmospheres $(A)$. 
The drying bluegrass gave the prairie its early dead appearance; the abundance of this invader could be estimated readily by the color of the landscape; in areas where Poa had been killed by two or three years of late burning, the prairie appeared as a continuous carpet of green.

Estival and autumnal forbs, which begin their growth in May and are ordinarily conspicuous because of rapid enlargement, developed slowly under the great evaporation stress resulting from the hot, dry, windy weather. This prevailing conditon was well illustrated by species of Zizia, Helianthus, Aster, Solidago, and many others. Moreover, late vernal bloomers were distinctly retarded in their usual activities. Anemone canadensis showed wilting, Galium tinctorium grew well only where it was protected by the grasses, Stcironema ciliatum and other species of the lower layers suffered severely from the drought. Certain short-lived, interstitial grasses, such as Festuca octoflora and F. ovina, failed to appear on the uplands. The shallowrooted rosettes of Erigeron ramosus of the previous summer and fall soon dried, and even the interstitial perennials, in the main, developed poorly, for not only was the soil dry but also the protecting clominant grasses had not macle their usual vigorous growth.

\section{Drought of Early Summer}

With the beginning of the estival aspect the last week in May the drought had become pronounced and was accentuated during the first week in June. At this time the spikes of Kocleria cristata were beginning to open, and Stipa spartea was in full bloom. Koeleria is a shallow-rooted grass, rarely exceeding 18 inches in depth. The flower stalks were greatly reduced in numbers and the length decreased from the usual 20 to 30 inches to only 5 to 8 inches. Moreover, the spikes were small and had very little viable seed. By the middle of May the meager foliage was tightly rolled, and the cauline leaves soon died. Koeleria had increased its osmotic pressure from about $16 \mathrm{~A}$ in early April to $25 \mathrm{~A}$ on May 10 . At the time of clrying, ten clays later, it had reached $36 A$.

The rather deeply rooted Stipa spartea occurs in greatest abundance on the ridges in soils not entirely appropriated by Andropogon scoparius. As early as the middle of May the effects of drought were evident. The usual 2- to 3 -foot vegetative stature was reduced to about 1 foot, and was scarcely exceeded by the flower stalks. Seeds were produced rather sparingly, and very few of them were well filled. The cauline leaves dried much earlier than usual; rolling of the basal leaves began about May 13 .

Panicum scribnerianum and $P$. wilcoxianum, representative of several interstitial species of minor grasses, blossomed scarcely at all. Instead the halfrolled, wilting leaves showed that the plants were in bad condition. They had made only a poor growth. Drought had not yet greatly affected the dominant bluestems, which are deeply rooted in the subsoil, except that lack of early 
rains had resulted in a somewhat sparser ground cover and slower growth. The normal deep green foliage over the uplands was slightly yellowish in color and only 5 to 7 inches in height instead of the usual 8 to 14 inches. The lighter color was undoubtedly correlated with a decreased nitrogen-fixing bacterial activity in the dry soil.

Antomnaria campestris was among the first forbs to indicate the exhaustion of surface soil moisture. The leaves had rolled early in May and no sap could be extracted from the leaves of plants from the higher slopes after May 10. Their adjustment to drought through increased osmotic pressure was only about $8 A$, a change from 10 to $18 A$ in about 20 days. Upon watering plants with withered and dry leaves, they recovered in a few hours as if by magic. The shallow root system of this and certain other species was indicated by lack of recovery when water was applied in trenches at a depth of 2.5 feet.

Quite in contrast was the behavior of Bouteloua gracilis, a short grass found only on the driest ridges. The osmotic pressure of $22 \mathrm{~A}$ on May 1 rapidly increased to $42 A$ by May 20 , and a little later reached the high value of $60 \mathrm{~A}$. Thereafter no sap could be extracted from this xeric immigrant from the Great Plains. It remained dormant and apparently dead but like Antennaria it revived quickly when water in the surface soil became available.

\section{Water Content of Soil}

By the first week in June water content of the soil was greatly reduced and drought had made a deep impress upon the uplands. It was ameliorated temporarily by a .64 inch shower on June 8 , and a similar one on the fourteenth. These rains, however, wet the parched soil only to a depth of 3 to 4 inches. A shower of .27 inch and another of .57 inch fell later in the month but any relief afforded was merely temporary. The total rainfall for June was only 2.47 inches. The July rainfall of .4 inch was dissipated in 7 showers.

Depletion of the water available for growth at various depths to four feet is shown in figure 1. Samples were taken in upland prairie from Carrington silt loam on a gentle south slope. The hygroscopic coefficients are as follows: 0 to 4 in., 10.8 per cent ; 4 to 12 in., $10.7 ; 1$ to $2 \mathrm{ft}$., $13.1 ; 2$ to $3 \mathrm{ft}$., 14.7 ; and 3 to $4 \mathrm{ft}$., 13.4 per cent. Examination of figure 1 shows the gradual depletion of the soil moisture at all depths with the progress of the season. Determinations at depths of 5 and 6 feet after midsummer showed that water was continuously available in small amounts at these levels.

\section{Responses of Grasses and Forbs}

By June 7, soil moisture was so depleted on the hilltops and higher slopes that the leaves of Andropogon scoparius were tightly folded and a few inches of the tips had dried. In many cases entire leaves had also dried, giving a reddish tinge to the bunches, which were poorly filled and only about half their 


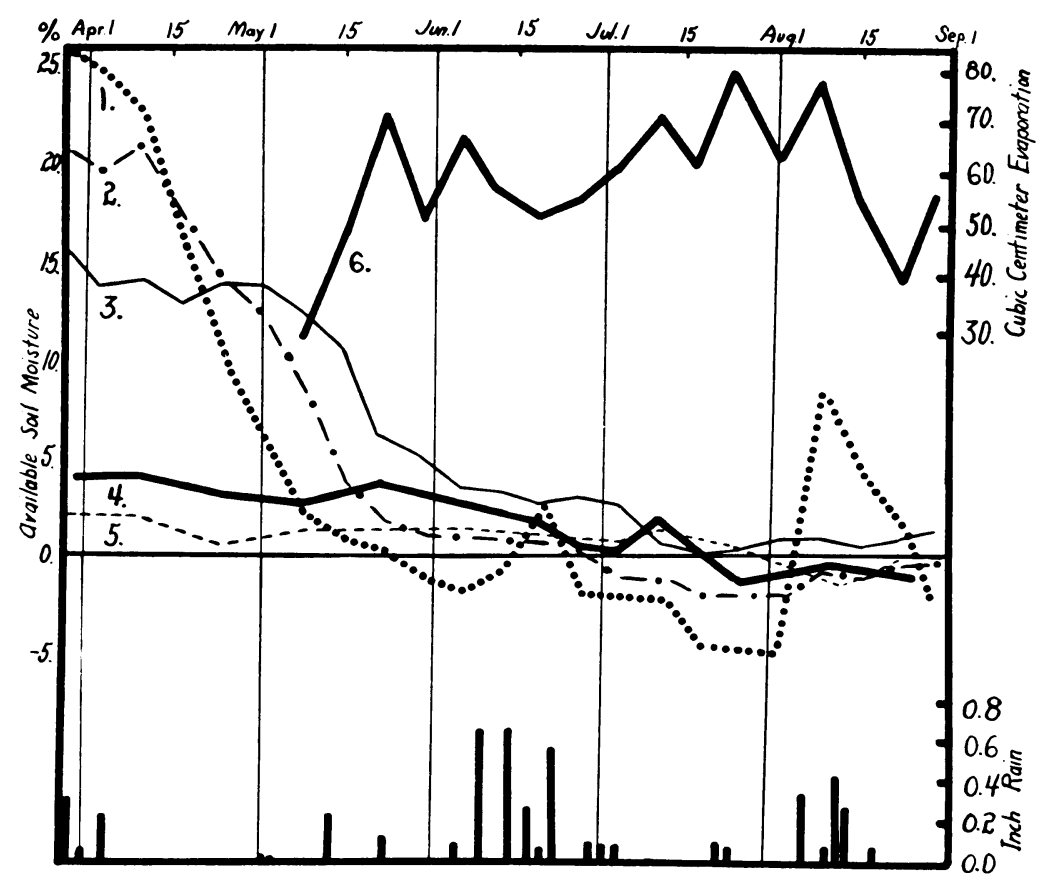

Fig. 1. Water content in excess of the hygroscopic coefficient at (1) $0-4$ in., (2) 4-12 in., (3) 1-2 ft., (4) 2-3 ft., and (5) 3-4 ft.; (6) the average daily evaporation by weeks from Livingston's white spherical atmometers; and the rainfall in inches.

normal height. The leaves of Sporobolus heterolcpis were tightly folded. Leaves of the more deeply rooted $A$. furcatus had begun to wilt, and in the driest places the bluestems had withered and turned brown as if visited by an early frost. Boutcloua curtipendula was wilted and the plants greatly dwarfecl. Sorghastrum nutans showed a wide range of conditions from plants that were entirely wilted to those with folded leaves. Clearly it was in greater distress than the more deeply rooted big bluestem, and appeared to have migrated too far up the slopes during years of abundant moisture (cf. Weaver and Fitzpatrick, '32).

Among the forbs, Achillea occidentalis had many dead leaves, half of those of Solidago rigida had clried, and Hicracium longipilum had much vilted foliage. Late in May the many shallow fibrous roots attached to the thick corm of Liatris scariosa could not meet the heavy demands of transpiration and wilting became common, finally recovery by night ceased, and late in June most of the tops died. Quite in contrast was L. punctata whose generalized taproot system penetrates the soil to 16 feet or more and absorbs water from a large soil volume. It remained unharmed even on the driest hilltops after all of the grasses were dried. The response of these two species to drought is in striking contrast both as regards their changes in osmotic pressure and re- 
tention of water within their tissues. The deeply rooted Liatris punctata maintained an osmotic pressure of 11 to $14 \mathrm{~A}$ throughout the growing season, and its water content decreased from 70 to only 56 per cent. The relatively shallow-rooted L. scariosa increased its osmotic pressure from 12 to $37 \mathrm{~A}$ and the water content decreased from 72 to 42 per cent.

Few seedlings of any species had started growth and these few were now dead. This was especially noticeable in Helianthus rigidus where also young plants from rhizomes had dead or wilted leaves. The stalks of Delphinium virescons were greatly dwarfed and the lower leaves dried. Erigcron ramosus was baclly wilted. The flower stalks were only 6 to 8 inches tall, unbranched or poorly branched, and the flowers were only half the normal size. Blossoming occurred early and was of short duration.

\section{Effect upon Flower Production}

The tendency to blossom early was marked in many species. Glycyrrhiza lepidota began blossoming late in May, and Pctalostemon candidus and $P$. purpurcus by the middle of June. The period of flowering in all cases was short. Solidago glabcrima had very yellow inflorescences by June 18 and the flowers opened on June 25, fully three weeks early. In general, the prairies were almost without flowers after June 15 and only scantily decorated after June 1. A few of the deeply rooted species (which extend 15 to 20 feet in the moist cool subsoil) produced flowers in extraordinary abundance. Among these were Psoralca floribunda, Mcriolix scrulata, and Rosa arkansana. Amorpha cancscons began blooming the first week in June instead of the latter part, as usual, but the flowering period was relatively short. Rosa arkansana, which normally continues to blossom well into July, had ceased blooming by the middle of June. Both Silphium laciniatum and S. integrifolium bloomed very early, while precocious plants of Kuhnia glutinosa were in flower on July 20.

\section{Appearance of Prairie Early in June}

Over the entire prairie there was a yellowish green tone rather than the characteristic one of deeper green. Since the grasses were short and the interstitial bluegrass dried, the grays and browns of last year's debris showed unusually well as the dry winds whipped the vegetation. The layer of Psoralea floribunda had developed well and added a dull green tone. A remarkable feature was the brighter green of the scattered tufts of big bluestem, which absorbs at depths of 6 to 7 feet, contrasting with the reddishbrown bunches of little bluestem, whose roots scarcely exceed 4 feet in depth.

On low ground the grasslands showed little effect of drought, on the slopes they were withstanding desiccation in a remarkable manner, but the thinner soils and drier areas on hilltops and upper slopes were clearly delimited by the drying vegetation. 
The unreplenished soil moisture was decreased daily by vigorous absorption by thirsty, half-wilted plants. The level of available water daily sank deeper. As drought began its steady and unhindered march down the slopes, responses of the various species to water deficit, as shown by wilting and drying or continuing unchanged, became clearly apparent.

\section{Relation of Depth of Rooting to Endurance of Drought}

Among the upland grasses Andropogon furcatus was last to succumb since its roots extended deepest. It remained green long after $A$. scoparius, Sporobolus hetcrolepis, and Boutcloua curtipendula were apparently wilted beyond recovery and after Stipa spartca had gone into its condition of droughtdormancy. Where quadrats had been clipped and the surface for transpiration, consequently, repeatedly reduced, big bluestem remained alive above ground many days after the unclipped plants had wilted. This phenomenon also was clearly evident in many half-cleteriorated prairie pastures where, though the soil was moist at a depth of four feet, the dominant bluegrass had (lried but the big bluestem and other deeply rooted species continued to draw the precious water.

Amorpla cancscons, excepting young plants, developed vegetatively as if there were no drought. It absorbs little in the surface two feet of soil but extends 12 to 15 feet into the cool moist earth. These plants appeared exceptionally robust because of the low stature of the grasses. Kuhnia glutinosa, with its root system extending 17 feet deep, behaved similarly. Its only unusual activity was its early flowering. Baptisia leucophaca showed no stress at any time, and like Amorpha ripened a large crop of seed. Its large taproot penetrates very deeply.

Rosa arkansana, with a woody taproot often 20 feet long, and younger offshoots closely connected to this main water highway, produced an unusually large crop of fruit and showed no wilting even during the greatest periods of stress. Liatris punctata maintained its foliage unwilted and was of normal stature. Notwithstanding the adverse conditions, it later flowered abundantly.

The deeply rooted Psoraleas all continued to thrive. P. esculenta seemed unusually abundant. It blossomed and fruited early and, as usual, the stem broke near the ground line and the plant was blown away. P. floribunda likewise seeded abundantly. Its efficient, deeply penetrating taproot system furnished sufficient water so that the plants never seemed to be under stress. The abscission of the stem and the death of the above-ground parts were no earlier than normal. The species common to lower grounds, P. argophylla, completed a normal annual cycle apparently unaffected by drought.

Aster multiflorus lost its lower leaves as usual but this deeply rooted plant which holds its water so tenaciously remained green even on the driest hilltops. The efficiency of the deep, fleshy, but little-branched taproot of Eclinacca pallida kept this species well supplied with water, except in the case 
of young plants. Both species of Pctalostcmon endured the drought well. Solidago rigidiuscula was a conspicuous survivor and showed a smaller mortality than did $S$. glaborrima. The latter spreads rapidiy and widely by means of rhizomes. Well established plants endured, but the mortality among the younger offshoots was often high. The large shrub, Ceanothus pubescens, rooted many feet (leep, showed no signs of wilting and made green the landscape over its entire range from midslope to hilltop.

\section{Retention of Water and Osmotic Pressures}

The graphs of water content of tissues and osmotic pressures of the cell sap of representative, moderately deeply rooted plants (fig. 2) and very deeply rooted upland species (fig. 3) show striking differences. Water content of the tops of Andropogon scoparius decreased from 77 per cent late in April to 52 late in May. The osmotic pressure showed a somewhat parallel increase

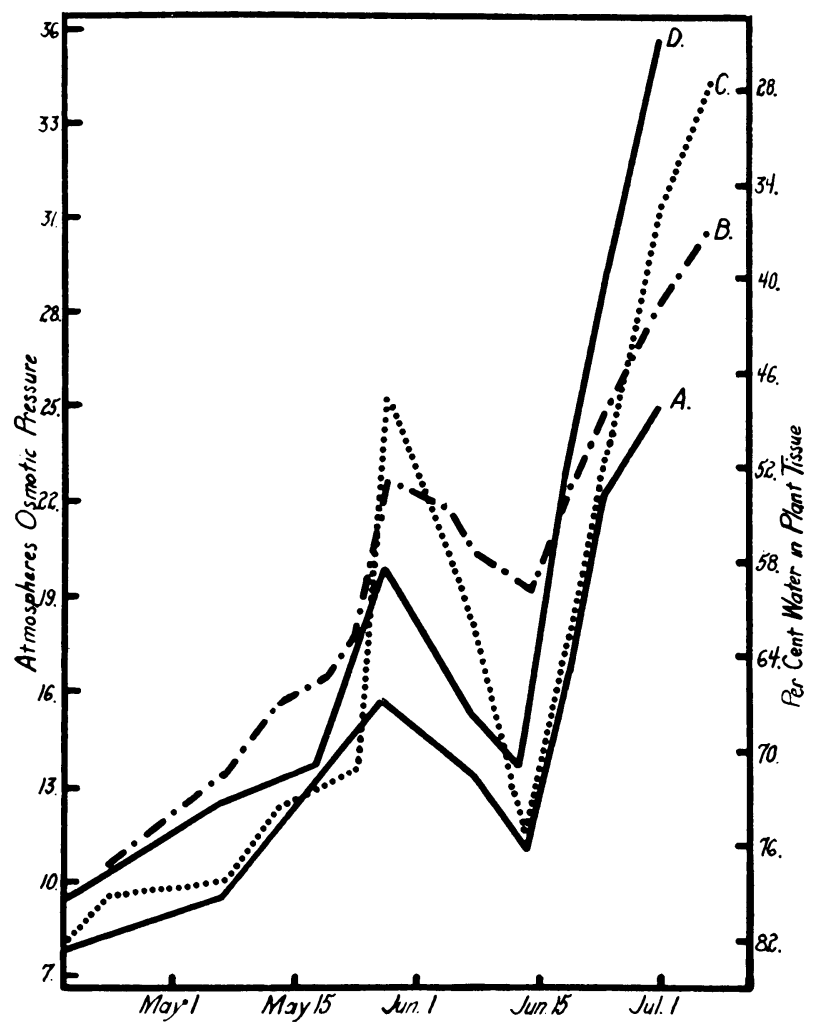

FIG. 2. Water content of $(A)$ Helianthus rigidus and $(B)$ Andropogon scoparius from April until the plants had dried. The temporary increase in water content in early June is due to showers, both species being well adapted to absorb in the surface soil. $(D)$ and $(C)$ show the osmotic pressures of the cell sap of the two species, respectively. 


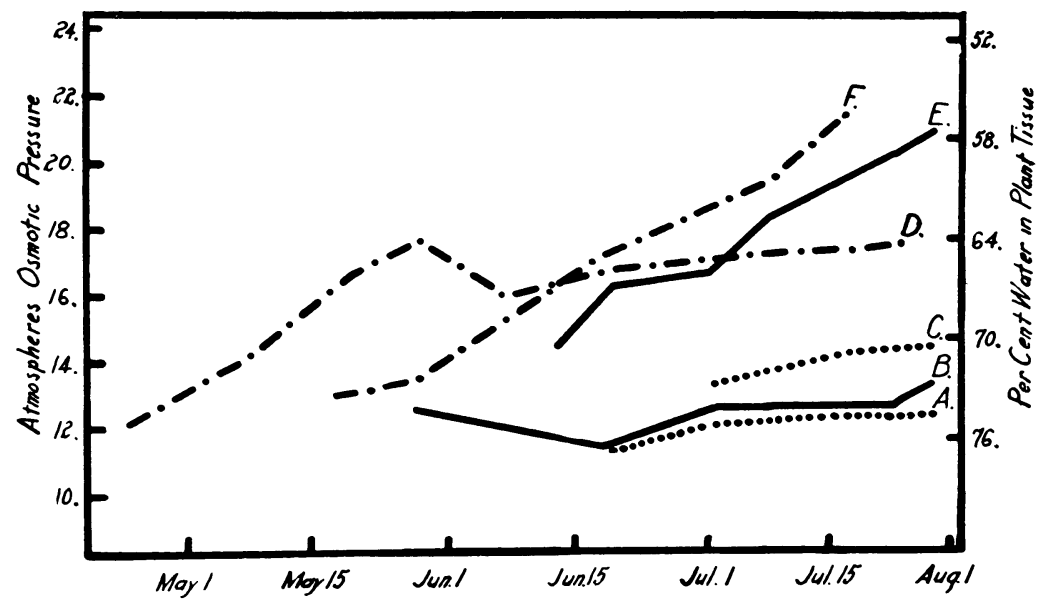

FIG. 3. Osmotic pressures of $(A)$ Kuhnia glutinosa, $(B)$ Liatris punctata, and $(D)$ Psoralea floribunda, all deeply rooted upland plants. Water content of tissues in the same sequence is shown in graphs $C, E$, and $F$.

from $8 A$ to $25 A$. A rain of .64 inch early in June, which wet the soil only 3 to 4 inches, increased the water content to 59 per cent and reduced the osmotic pressure to $12 \mathrm{~A}$. With the continued depletion of the subsoil moisture, however, the water content within the plant was decreased to 36 per cent. The osmotic pressure rose rapidly to $35 \mathrm{~A}$ before the tops died. The parallelism between the decreasing water content and increasing osmotic pressure is very similar in Helianthus rigidus as is also the response to the increased surface soil moisture due to the June rain. The tenacity with which both species persisted after weeks of semi-wilting was impressive.

The deeply rooted species showed a more complacent existence, for water was to be had, even if in small amounts, from all levels in the subsoil (fig. 3 ). This available subsoil moisture may be completely utilized by a crop of alfalfa over a period of ten or more years, but in scores of trenches dug in the tallgrass prairie in excavating roots, a dry subsoil under a cover of natural vegetation has never been encountered. Neither water content of the tissues of Kuhnia glutinosa nor its osmotic pressure changed to any marked degree. Although the water content of the above-ground parts of Liatris punctata decreased from 70 to 56 per cent, the osmotic pressure remained nearly constant, and the plants showed no wilting. Osmotic pressure of Psoralea floribunda during June and July was remarkably constant despite the severity of the drought. It is entirely possible that the gradual decrease in water content of tissue from 72 to 56 per cent is a natural physiological process in this species, which gradually develops an abscission layer near the ground line during July.

Among the deeply rooted and consequently unwilted species of lower slopes some of the more important were Artemisia gnaphalodes, Asclepias tuberosa, Glycyrrhiza lepidota, Silphium integrifolium, and S. laciniatum. None suf- 
fered from wilting; flowering and seed production proceeded apparently in a normal manner, except that they were earlier than usual. Salvia pitcheri, even when it occurred on higher slopes, also withstood the ravages of drought in a remarkable manner. All these deeply rooted species persisted until fall.

That the wilting and drying of the prairie plants was not due to the high temperatures and low humidities alone, but primarily to low water content of soil was shown in many ways. Heliantlus rigidus, for example, was often completely wilted and the leaves dried even in the big bluestem sod, while a foot or two distant in cultivated land, the same species was 3 or more feet tall, abundantly supplied with flower heads and entirely turgid. In the main, this species held out well until early July, the wilted plants with leaves half folded persisting for a long time. Finally, many succumbed to the drought. Where local areas in the prairie were heavily watered, not only the revived grasses but all of the forbs as well continued throughout the hottest and driest period without noticeable wilting. The grasses renewed growth, several proceeded to blossom. Forbs that could not be found elsewhere reappeared together with numerous seedlings. Some that had ceased blossoming burst forth in full bloom. The osmotic pressure and the water content of the newly grown tissues of both grasses and forbs were approximately those of the same species before the occurrence of the drought.

\section{The Midsum mer Drought}

The most trying period began about June 20. Before its advent the tops of many species were almost entirely wilted, some had dried. Chief among these were Drymocallis agrimonioides, Anemone cylindrica (except on the lowest ground), Comandra umbellata, Mesadenia tuberosa, Gentiana puberula, Aclillea occidentalis, Phy'salis lanceolata, and Erigeron ramosus. The half-cured little bluestem of hilltops and xeric slopes crunched like snow under one's tread, and the local areas of grama grass were completely dried. Even the accompanying big bluestem was half dried. Then followed a period of most intensive drought. A terrific heat wave swept over the prairie. It continued until the last week in July. During this period the scorching sun seared the prairie as if by fire, and life in all but the most deeply rooted species retreated underground.

\section{Enitronment During the Most Intense Period of Drought}

In figure 4 it may be seen that the average daily maximum temperature increased week by week from $88^{\circ} \mathrm{F}$. to $111^{\circ} \mathrm{F}$. The average day temperature ( 6 A.M. to 8 P.M. inclusive) ranged upward from $77^{\circ} \mathrm{F}$. to over $100^{\circ} \mathrm{F}$. Even the average daily minimum temperature ranged mostly between $70^{\circ}$ and $78^{\circ} \mathrm{F}$. Accompanying these extreme temperatures was an average day humiclity (including the 8 P.M. reading) that decreased from 48 to only 23 per cent. The average daily maximum humiclity exceeded 70 per cent only 
early in the period but finally decreased to 40 per cent. The average daily minimum humidity over a period of six weeks dicl not exceed 22 per cent and it was as low as 15 per cent. On some afternoons the humidity decreased to 5 per cent and once to 3 per cent.

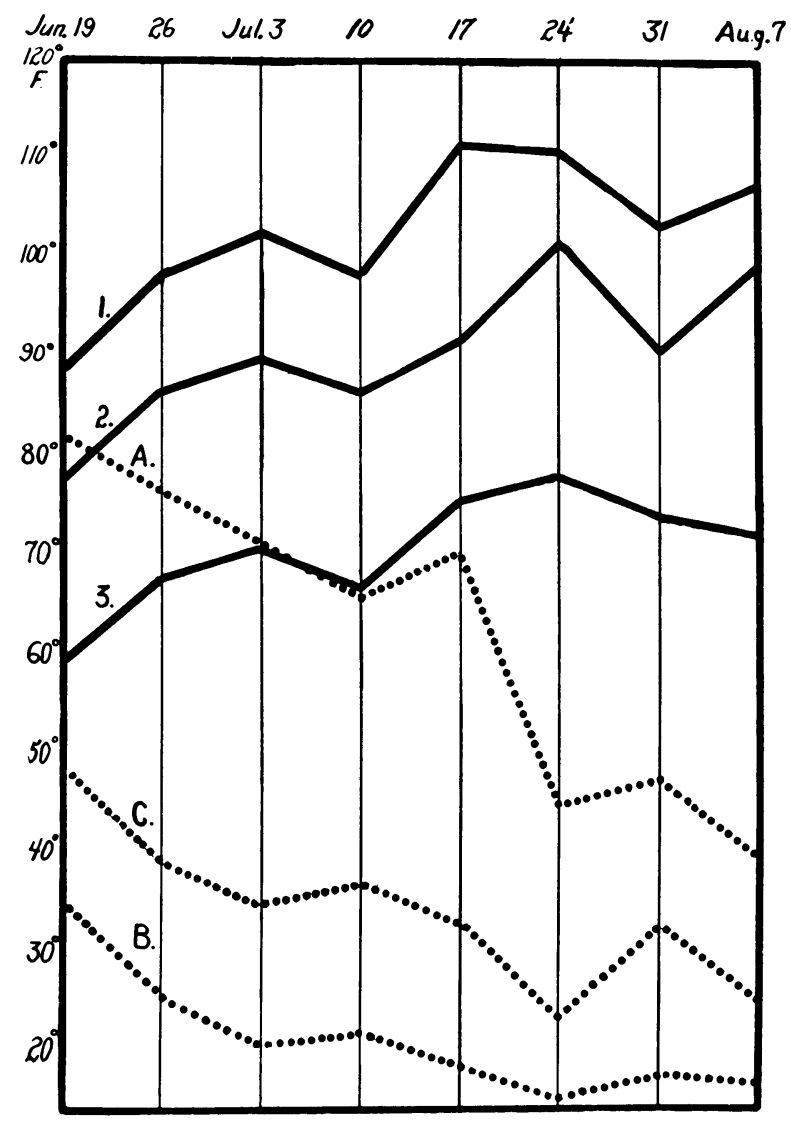

FIG. 4. Temperature and humidity during the most intense period of drought. (1) Average daily maximum temperature, (2) average day temperature, and (3) average daily minimum temperature by weeks. ( $A$ ) Average daily maximum humidity, $(B)$ average daily minimum humidity, and $(C)$ average day humidity by weeks. Degrees $\mathrm{F}$. and per cent relative humidity are represented by the same scale.

Accompanying these extremes was an available water content exhausted to the one-foot level with a very dry subsoil at the beginning of the period and to four feet at the end. Wind movement was often high, averaging over 10 miles per hour during July. Rates of evaporation (fig. 1) were often twice and sometimes nearly three times as great as those recorded in the prairie during the three preceding years (Flory, '34). These are the factors that intensified the drought. Where the water supply was maintained no injury 
was done although water loss from a single square foot of the little bluestem vegetation, which was only 5 to 6 inches tall, was sometimes 1.5 pounds per dlay.

No rain fell; clouds were rare, in fact during the latter half of the period they seldom formed. The light was intense, the dust-filled, yellow, western sky in evening portending another day of drought. The hot southerly winds blew as from a desert; drought that had bleached the green hilltops to patches of brown alternating with white, now crept down the slopes. In pastures and fields great cracks had formed in the soil, increasing greatly the surfaces for soil moisture evaporation and furnishing ready escape for the water vapor diffusing from the soil, perhaps at a depth of 2 to 3 feet. But in the prairie, because of the unmodified soil structure held by roots and rhizomes and covered with a mantle of vegetation, no cracks were observed. A 14- to 18-inch $A$ horizon sealed over the great network of open spaces surrounding the columns formed in the $B$ horizon by the shrinking of the deeper soil of higher clay content.

\section{Appearance of the Prairie in July'}

By the middle of July the tops and drier slopes of the prairie-covered hills appeared almost as dry as the bluegrass pastures. A week later the area of dried grasses had extended well down the slopes, those facing westward and southward becoming nearly as dry as the uplands. The advantages of areas such as ravines that had received run-off water to wet the soil the previous year were outstanding. Even on the lower slopes and in the ravines the deeper greens of May had been bleached to the yellow green characteristic of drought. On north-facing hillsides the belt of green extended upward only a little way.

Little bluestem was practically all dried on the uplands. Sporobolus hctcrolcpis had yielded a little slower, its greater drought resistance being shown not only by its striking yellow-green bunches among the dried bluestem but also by its rapid recovery through basal leaf growth upon watering. The little bluestem when watered produced an entirely new crop of foliage. A few tightly rolled green leaves persisted in the bunches of Stipa spartea. In this respect it resembled Agropyron smithii, which occurred very sparingly. Both of these species unrolled their leaves and revived quickly upon watering. Koeleria cristata was entirely dried as was also Bouteloua curtipendula. Agrostis hyemalis and Eragrostis pectinacea did not bloom. Sorghastrum mutans had succumbed and also, among the last, Andropogon furcatus.

The persistence of the grasses and forbs was remarkable. Silphium laciniatum, although attaining only half its normal stature, blossomed on some uplands. In societies of Coreopsis palmata the dwarfed plants were half dead. Aster sericeus was defoliated to near the top, but species of Acerates 
seemed unharmed. Euphorbia corollata retained only a few of its upper leaves, in some cases all had fallen, yet the dwarfed plants continued to bloom. Only after days of wilting and rolling or folding of the leaves, weeks of battling the intense heat, high winds, and low humiclities uncler the cloudless skies did life finally retreat underground to await the advent of rain. The bronzes, yellows, and golds, colors normally appearing late in autumn, were of short duration. For soon the blazing sun had scorched the withered grasses until the prairie had the bleached appearance common to the late winter aspect. The plants appeared dead and brown, and when walked upon quantities of the dust brought in by early wind storms arose from them.

Unlike a field of maize, wheat, or clover which can sometimes be ruined by a few days of severe drought, the native forbs yielded only a little each day. Neither were their leaves torn and frayed by the wind as were those of cultivated crops. There were no blossoms to tell the seasonal aspect for the oven-like heat and dryness prevented flowering. Many square meters were without a living green thing.

As the weeks passed without rain, even the lowlands began to reveal the impact of drought. By August 5, at the end of the continued heat wave, the bluestem grasses had lost their green color and were wilted and dried even on the lowest slopes. This indicated that the water supply within reach of the roots was practically exhausted even on the low ground. The progress of drying of the big bluestem is of interest. First the two or three basal leaves of a plant turned brown and died. Simultaneously or a little later the remaining leaves died at the tip and then progressively towards the base as drought increased. This grass had nowhere attained its usual 18 to 24 inches in height and was only 9 to 11 inches tall. With the drying of the foliage of the big bluestem, much dwarfed specimens of Panicum virgatum and Elymus canadensis that had migrated outward too far from their proper place fringing the Spartina michauxiana communities in the ravines, showed great distress. The tenacity with which Panicum persists, even on uplands where it has become established in clisturbed areas, is remarkable. But it and the marginal slough grass were now bleached yellowish green and were about to dry. Panicum virgatum possesses the deepest root system of any of the grasses of the tall-grass prairie. Elymus, which is only moderately deeply rooted, had, in general, developed poorly.

Many species at home on these usually moist slopes were breaking under the drought. Hieracium langipilum began drying while in early bloom with its flower stalks only one-third elongated. Rhus toxicodendron, fully exposed to the sun because of the scanty growth of grasses, was burned and the leaves dried and bleached. Equisetum lacvigatum had lost half its stems, which bleached white in the sun, and the remainder were drying at the tops. Meibomia illinoensis, although in fruit, was rapidly drying except in the most favored places as was also Lespedeza capitata. Helianthus grosseserratus, spreading outward from its strongholds in the ravines, was greatly dwarfed 
and wilted. This was true also for other marginal species such as Hcliopsis scabra, Helianthus tuberosus, Monarda fistulosa, and Teucrium canadense. A few species, such as Vernonia baldwini, Asclepias sullivantii, and Silphium integrifolium, grew normally and stood unwilted above the dried grasses.

The very slow decrease in the water content of the tissues of representative forbs and grasses, all deeply rooted in the formerly wet soil of the ravines, is shown in figure 5. The average decrease from early spring to August 1 was from about 80 to 60 per cent. The osmotic pressure showed even less change, increasing only 2 to $3 A$ from April to June, and 1 to $2 A$ more by August 1. These slight changes would probably also characterize upland plants during normal seasons with plentiful soil moisture.

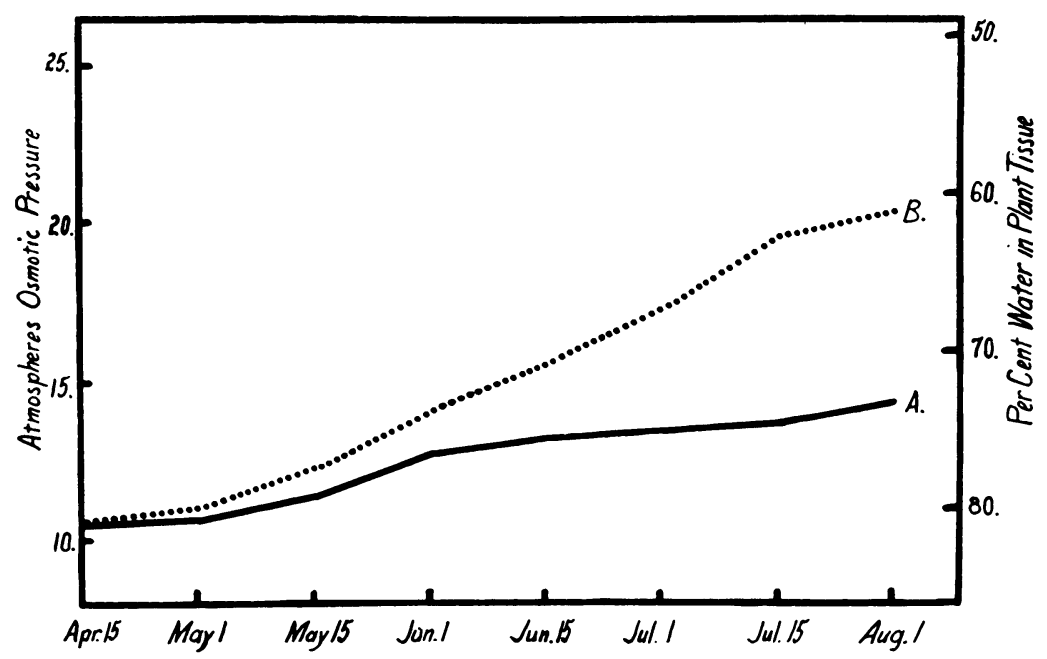

Fig. 5. ( $A$ ) Average osmotic pressure and $(B)$ average water content of five species of lowlands, viz.: Helianthus grosseserratus, Aster salicifolius, Solidayo altissima, Panicum virgatum, and relict Spartina michauxiana.

The drought also left a deep impress upon the vegetation in sloughgrass alternes and wetter areas of the ravines. On the Belmont prairie, for example, the water table had been lowered by the first week in August to 5.5 feet where normally it is at or near the soil surface. Although Phalaris arundinacea was only half clried, alternes of Carex inlpinoidea were burned brown. Carex had undergone a reduction in water content of tissues from 69 to 33 per cent, and an increase in osmotic pressure from 12 to $41 \mathrm{~A}$. The decrease in water content of Phalaris was from 80 to 60 per cent, and the osmotic pressure increased from 14 to $22 \mathrm{~A}$. Scirpus atrovirens was half dried and had produced no seed. Spartina was dwarfed, the ends of the leaves were brown, and the plants with rolled leaves were half dried. In relict patches of Typha latifolia, the plants, which had headed at about 4 feet, were so dry that scarcely any green tissue remained. Their osmotic pressure 
rose from 6 to $19 A$ and the water content clecreased from 87 to 72 per cent by July 15. The understory of Lecrsia oryzoides was dead and dry. Characteristic swamp species such as Verbena hastata, Asclepias incarnata, and Bidens bifinnata were wilted even in early morning.

\section{Drought of Late Summer}

Scattered showers and periods of cool weather mitigated the drought after the first week in August. A rainfall of .36 inch occurred on the sixth, .51 on the twelfth and thirteenth, and the drought was finally ended by 1.33 inches of rain at the end of the month.

\section{Behazior of Species on Uplands}

The responses of the grasses, that were not entirely dried alove ground, were marked for a few clays after each shower. The few green leaves still alive among the bunches of Stipa spartea unrolled. But many of the bunches showed no greening. Some leaves in the most resistant tufts and bunches of Andropogon furcatus, Boutcloua curtipendula, and Sporoholus heterolepis renewerl growth at the hase. Also a few new leaves appeared. Even some of the most deeply rooted plants of Andropogon scoparius began to put forth new foliage. But such greening and growth were not continuous nor did they occur generally. Growth had scarcely gotten well under way before the surface water supply was again exhausted. The persistence of scattered individuals of a species that in general had died above ground was of much interest. A single bunch of little bluestem with a few persistent green leaves, a plant of Gontiana pubcrula, or an inclividual of Liatris scariosa persisting in spite of the drought, are typical examples. One had to observe closely to perceive the new development; the local tone was yellowish green rather than bright green, and both in the uplands and valleys the general bleached aspect of the prairie remained unchanged. Poa pratensis, Kocleria cristata, Antemaria campestris, and many other species made no new growth.

The general height of the upland grasses varied from about + to 7 inches; in places it did not exceed 3 inches. The cover was conspicuonsly open, and where spring burning had occurred much soil was bare. The basal cover averaged perhaps 15 to 20 per cent less than normal.

The forlos that had been killed above ground showed little or no renewal of growth. The deeply rooted ones that endured the midsummer drought still remained green, although not the deep green of a moist summer. The deeply rooted upland plants slightly decreased their osmotic pressures late in August, as a result of the increased soil moisture and humidity. Water content of tissues increased very slightly. Less deeply rooted species, that also depended somewhat upon surface soil moisture, were somewhat revived and showerl a decrease in osmotic pressures of 6 to $10 \mathrm{~A}$. 
On lower slopes Asclepias tubcrosa had lost scarcely a single leaf. Gray societies of Artemisia gnaphalodes decorated the somber landscape. Others of Glycyrrhiza lcpidota, brown with ripened fruits overtopped with the green foliage, showed conspicuously above the short growth of dried bluestems. Vernonia baldwini flowered early and the inflorescence was dry in late August. Ceanothus pubescens still remained green; Amorpha canescens lost its lower leaves as is usual in August; Rosa arkansana continued functioning as if the year were quite normal; and Liatris punctata showed no signs of drought. Among the upland goldenrods, Solidago rigidiuscula was affected least; $S$. glaberrima likewise persisted everywhere, but after severe mortality and the loss of lower leaves. Echinacea pallida, Petalostemon candidus, and P. purpurcus also showed great resistance to drought and remained green until late fall. Mcibomia illinoensis was considerably defoliated. Many wilted plants of Hclianthus rigidus regained turgidity and survived; they were greatly dwarfed, produced no flowers, and maintained only a few pairs of terminal leaves. Silphimm laciniatum and S. integrifolium bloomed early; the stems were usually short. Aster multiflorus persisted even on the driest ridges, as dicl also Kuhnia glutinosa and Euphorbia corollata, the last two frequently in great abundance. Often the abundant, showy inflorescences of the flowering spurge alone gave tone to the landscape.

The early autumnal aspect was indeed poor. Scattered throughout were flowers of Solidago glaberrima, more abundant ones of the less conspicuous Kuhnia glutinosa, and an occasional Physalis lanceolata in full bloom. On lower slopes the bright blue flowers of Salvia pitcheri occurred but not abundantly, and the yellows of Oenothera biemis showed occasionally.

\section{Behavior of Species on Lowlands}

In the ravines the ravages of drought proceeded steadily but slowly. At Belmont prairie near the end of August, saturated soil was found only at a depth of 6.5 feet. Such characteristic species as Aster salicifolius, Solidago altissina, and Helianthus grosseserratus were developing flower heads on stalks only one-half to two-thirds the height of the dried stems of the previous year. Helianthus had lost all but the top 4 to 6 inches of foliage. Some of the plants were wilted. Many species showed by dwarfness, wilting, and drying considerable deterioration since early August.

On the lowlands along the Missouri River, where drought was belated by 4 inches of rain in June, growth had ceased by July 20 . After this shortage of water was continuous although the water table under the big bluestem is normally only 7 to 9 feet deep (Weaver, et al, '35). In August the foliage of Andropogon furcatus, commonly 2.5 to 3 feet high, averaged only 22 inches. Whole meadows appeared semi-wilted; the drying grass rustled as one walked through it. The usual deep green had been replaced by the yellowish greens, reds, and bronzes of late autumn. Scarcely a flower stalk could be found. 
Where sandy or gravelly soil replaced the heavy loam, the grass was dead. Plants forming the conspicuous understory began dying early in July and were now completely dried. The most conspicuous were Fragaria virginiana, Steironema ciliatum, Ancmone canadensis, Galium tinctorium, and Equisctum aricusc. Panicum airgatum was even more poorly developed than big bluestem. The panicles, which appeared very early, were only 2 to 3 feet tall compared to the usual stature of 5 to 5.5 feet. The foliage was yellowish in color and many leaves were dried. Elymus canadensis was reduced proportionately in height. The foliage of Spartina michantiana reached only 3.5 to 4.5 feet, which is a little more than half the usual stature. It had a light green color. The flower stalks, which often reach heights of 7 to 9 feet, were scarcely taller than the foliage.

After the rains of early September the grasses of both uplands and lowlands marle some new growth, but the season was too far advanced for much development. Many clumps of several species appeared dead. Numerous permanent quarlats have been mapped so that the further history of the vegetation may be determined during the next growing season.

\section{SUMIIARY}

The most severe drought ever recorded in the prairies of eastern Nebraska occurred during 1934. Water content of the upland was gradually depleted, and by July 30 no water to a depth of + feet was available for growth. During July the average maximum daily temperature varied from $98^{\circ}$ to $111^{\circ}$ F. and the average minimum daily humidity from 15 to 22 per cent.

Blossoms of deeply rooted plants marked the vernal and estival aspects. Flowering often began 2 to 3 weeks earlier than normal and was of shorter duration. Poa pratensis, Koelcria cristata, Antennaria campestris, and other shallowly rooted species dried in May, developing osmotic pressures of only 18 to 27 atmospheres. Andropogon scoparius in the dry upland soils withered early in June; A. furcatus, because of its deeper root system, persisted a longer time. Stipa spartea and Boutcloua gracilis were more resistant, rolling their leaves and assuming a condition of drought-dormancy.

Among the forbs, resistance to drought was closely correlated with root extent. Species with root systems penetrating 8 to 20 feet into the moist subsoil were little affected. Water content of tissues decreased but little with the progress of drought and increase in osmotic pressure was slight. Where the root systems were shallow and less efficient, decrease in water content of tissues was pronounced, and increase in osmotic pressures was 8 to 38 A. Many species wilted and dried.

Drought swept from hilltops down the slopes into mesic and hydric ravines. Wilting and drying were not due alone to high temperatures and low humidities but primarily to low water content of soil, since plants in watered areas thrived. 


\section{Literature Citeil}

Flory, E. L. 1934. Comparison of the environment and some physiological responses of prairie vegetation and cultivated corn. Unpublished MS.

Weaver, J. E. 1919. The ecological relations of roots. Carn. Inst. Wash. Publ. 286.

- 1920. Root development in the grassland formation. Carn. Inst. Wash. Publ. 292.

—, and W. J. Himmel. 1931. The environment of the prairie. Cons. and Surv. Dia'. Uniz. Vebr. Bull. 5.

—, and T. J. Fitzpatrick. 1932. Fcology and relative importance of the dominants of tall-grass prairie. Bot. Gaz. 93: 113-150. - _- 1934. The prairie. licol. Monog. 4: 111-295.

—, V. Hougen, and M. D. Weldon. 1935. Relation of root distribution to organic matter in prairie soil. Bot. Gas. 96: 389-420. 